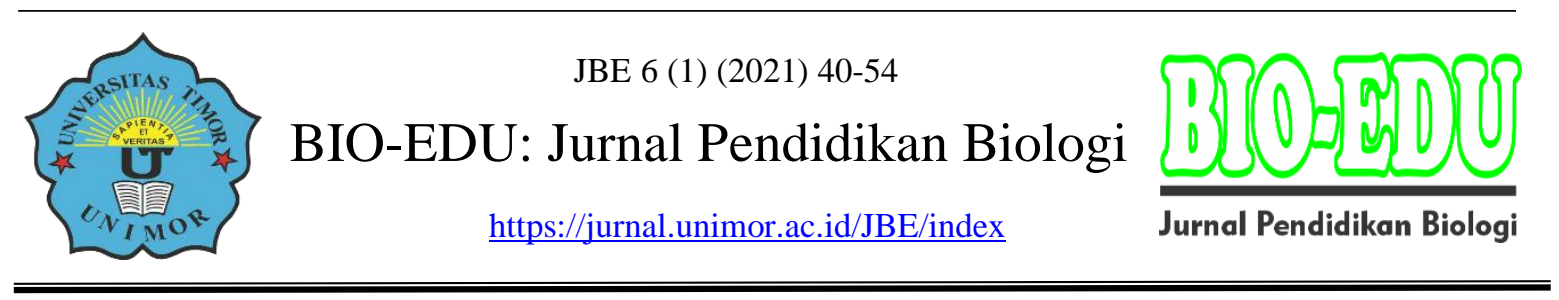

\title{
Pengaruh Model Pembelajaran Contextual Teaching and Learning (CTL) Terhadap Hasil Belajar Kognitif dan Literasi Sains Siswa
}

\author{
Safnowandi \\ Program Studi Pendidikan Biologi, Fakultas Sains, Teknik, dan Terapan, \\ Universitas Pendidikan Mandalika, Mataram, Indonesia \\ Jalan Pemuda Nomor 59A Mataram \\ safnowandi_bio@ikipmataram.ac.id
}

DOI: https://doi.org/10.32938/jbe.v6i1.831

\begin{abstract}
Abstrak
Tujuan penelitian ini adalah untuk: 1) mengetahui pengaruh model pembelajaran Contextual Teaching and Learning (CTL) terhadap hasil belajar kognitif; dan 2) untuk mengetahui pengaruh model pembelajaran Contextual Teaching and Learning (CTL) terhadap literasi sains siswa. Jenis penelitian ini adalah eksperimen semu. Desain penelitian pre-test-post-test non equivalent control group design. Populasi dalam penelitian ini adalah seluruh siswa kelas VII SMPN 1 Kabupaten Lombok Utara tahun pelajaran 2017/2018 yang terdiri dari 6 kelas. Teknik pengambilan sampel menggunakan purposive sampling, sehingga diperoleh kelas VII 3 sebagai kelas eksperimen dan kelas VII 1 sebagai kelas kontrol. Instrumen yang digunakan untuk mengumpulkan data adalah soal pilihan ganda yang berjumlah 20 butir untuk mengukur hasil belajar kognitif siswa dan soal uraian untuk mengukur isi dan konteks keilmuan. Sedangkan LKS digunakan untuk mengukur proses ilmiah. Teknik analisis data menggunakan ANOVA dua jalur dengan taraf signifikansi 0,05\% menggunakan program SPSS 16 for Windows. Hasil penelitian menunjukkan bahwa: 1) terdapat pengaruh penerapan model pembelajaran Contextual Teaching and Learning (CTL) terhadap hasil belajar kognitif ( $<<0,05)$; dan 2) terdapat pengaruh model pembelajaran Contextual Teaching and Learning (CTL) terhadap literasi sains siswa $(\mathrm{p}<0,05)$.
\end{abstract}

Kata Kunci: Contextual Teaching and Learning (CTL); Hasil Belajar Kognitif; Literasi Sains.

\begin{abstract}
The objectives of this research are to: 1) determine the effect of the Contextual Teaching and Learning (CTL) learning model on cognitive learning outcomes; and 2) to determine the effect of the Contextual Teaching and Learning (CTL) learning model on students' scientific literacy. This type of research is a quasi experiment. The research design of pre-test-post-test non equivalent control group design. The population in this study were all class VII students of SMPN 1 Tanjung North Lombok Regency in the academic year 2017/2018 which consisted of 6 classes. The sampling technique used purposive sampling, in order to obtain class VII 3 as the experimental class and class VII 1 as the control class. The instruments used to collect data were multiple choice questions totaling 20 items to measure student cognitive learning outcomes and essay questions to measure content and the scientific context. Meanwhile, worksheets are used to measure the scientific process. The data analysis technique used twoway ANOVA with a significance level of $0.05 \%$ using SPSS 16 for Windows. The results showed that: 1) there was an effect of the application of the Contextual Teaching and Learning (CTL) learning model on cognitive learning outcomes ( $\mathrm{p}<0.05)$; and 2) there is an effect of the Contextual Teaching and Learning (CTL) learning model on students' scientific literacy $(\mathrm{p}<0.05)$.
\end{abstract}

Keywords: Contextual Teaching and Learning (CTL); Cognitive Learning Outcomes; Science Literacy. 


\section{PENDAHULUAN}

Undang-Undang Dasar Negara Republik Indonesia Tahun 1945 berfungsi untuk mengembangkan kemampuan dan membentuk watak serta peradaban bangsa dengan mengoptimalkan potensi peserta didik agar menjadi manusia yang beriman dan bertakwa kepada Tuhan Yang Maha Esa, berahlak mulia, sehat, beilmu, cakap, kreatif, mandiri, menjadi warga negara yang demokratis, dan bertanggung jawab (BSNP, 2006 dalam Yaum, 2013). Pendidikan merupakan suatu proses dalam rangka mempengaruhi siswa agar dapat menyusuaikan diri sebaik mungkin dengan lingkungannya sehingga menimbulkan perubahan dalam dirinya yang memungkinkan untuk berfungsi secara cakup atau memandai dalam kehidupan masyarakat (Hamalik, 2003 dalam Yaum, 2013).

Kondisi belajar siswa belum optimal karena masih didominasi oleh pembelajaran konvensional dan hanya mengejar target yang berorientasi pada ujian akhir, sehingga dalam pembelajaran tersebut para siswa selalu diposisikan sebagai pemerhati ceramah guru, sehingga kurang diberdayakan untuk mau dan mampu berbuat dalam memperkaya pengalaman belajar dan meningkatkan interaksi dengan lingkungan sehingga kurang bisa membangun pemahaman dan pengetahuan terhadap dunia di sekitar dan kurang memiliki kesempatan untuk membangun pengetahuan dan kepercayaan diri maupun kemampuan untuk berinterakasi dengan berbagai individu atau kelompok yang beragam di masyarakat (Sukerthi, 2013).

Berdasarkan observasi di lapangan pada bidang studi IPA kelas VII di SMPN 1 Tanjung masih banyak siswa mengalami hasil belajar yang rendah karena tidak mencapai kriteria ketuntasan minimal (KKM), siswa masih pasif dalam menanggapai serta mamahami materi yang diajarkan dalam proses pembelajaran, dan siswa sering beranggapan bahwa pelajaran IPA itu sangat membosankan dan sulit. Selama ini dalam proses pembelajaran IPA guru juga masih cendrung menggunakan metode konvensional seperti ceramah dan diskusi. Proses pembelajaran yang seperti itu tidak efektif dan efisien untuk meningkatakan prestasi dan hasil belajar siswa dalam pelajaran, sehingga prestasi rata-rata hasil belajar siswa di bidang studi IPA masih rendah dan belum mencapai kriteria ketuntasan minimal (KKM) yang telah ditentukan oleh sekolah. Hal ini dapat dilihat dari nilai rata-rata MID semester I. Gambaran nilai yang diperoleh siswa kelas VII yaitu KKM pelajaran IPA adalah 70 , persentasi dengan nilai rata-rata $\leq 70$ yaitu $63,35 \%$. Dari hasil persentasi nilai tersebut, maka perlu adanya perlakuan baru guna untuk mengetahui perubahan nilai siswa.

Pembelajaran IPA di kelas VII SMPN 1 Tanjung masih banyak siswa yang mengalami kesulitan dalam memahami konsep yang diajarkan. Hal ini berdasarkan dari hasil observasi dan wawancara dengan guru bidang studi IPA, bahwa di SMPN 1 Tanjung, model CTL yg diterapkan oleh gurunya sangat sederhana. di mana siswa hanya diberi materi tanpa dikaitkan dengan kehidupan nyata atau kehidupan riil siswa sehingga kemampuan sangat terbatas untuk mengaplikasikan materi atau pengetahuan yang dimilikinya. Berdasarkan hasil penerapan model tersebut terlihat bahwa siswa kurang mengetahui tentang alam secara sistematis dan penguasaan kumpulan pengetahuan yang berupa fakta-fakta masih sangat kurang. Rendahnya prestasi belajar siswa disebabkan oleh rendahnya tingkat penguasaan siswa terhadap konsep-konsep. Ilmuwan literasi sains akan dapat berkontribusi terhadap kesejahteraan baik dari aspek sosial maupun ekonomi 
(Hendriani, 2013). Pemahaman tentang sains siswa juga masih kurang, karena meraka masih berpatokkan dengan buku dan pembelajarannya masih cenderung patokkannya pada guru, sehingga mereka tidak bisa mengaplikasikan antara materi yang mereka pelajari dengan kehidupan sehari-hari.

Salah satu model pembelajaran yang sesuai untuk meningkatkan hasil belajar kognitif dan literasi sains adalah model pembelajaran Contextual Teacing and Learning (CTL) merupakan metode belajar yang membantu semua guru mempraktikkan dan mengaitkan antara materi yang diajarkan dengan situasi yang ada dilingkungan siswa dan menuntut siswa membuat hubungan beberapa pengetahuan yang pernah dialami siswa dengan penerapannya dalam kehidupan mereka sebagai angota keluarga dan masyarakat, dengan konsep itu, hasil pembelajaran diharapkan lebih bermakna bagi siswa karena proses pembelajaran berlangsung alamiah dalam bentuk kegiatan sehingga siswa mengalami bekerja secara langsung, bukan mentransferkan pengetahuan dari guru kesiswa (Amri, 2010).

Pengajaran CTL adalah pembelajaran yang memungkinkan siswa- siswia untuk menguatkan, memperluaskan, dan menerapkan pengetahuan dan keterampilan akademik dalam berbagai macam tatanan dalam sekolah dan luar sekolah, agar dapat memecahkan masalah-masalah dunia nyata atau masalah yang disimulasi. Pembelajaran kontekstual terjadi apabila siswa menerapkan dan mengalami apa yang sedang diajarkan dengan mengacu pada masalah- masalah dunia nyata yang berhubungan dengan peran dan tanggung jawab mereka sebagai siswa, pembelajaran kontekstual adalah pembelajran yang terjadi dalam hubungan yang erat dengan pengalaman sesungguhnya. CTL menekankan pada berpikir tingkat lebih tinggi, transfer pengetahuan lintas disiplin, pengumpulan, penganalisaan dan pensintesisan informasi dan data dari berbagai sumber dan pandangan. Disamping itu, diidentifikasikan enem unsur kunci CTL seperti, pembelajran bemakna, penerapan pengetahuan, berpikir tingkat lebih tinggi, kurikulum yang dikembangkan berdasarkan standar, rensponsif terhadap budaya, dan penilaian autentik (Trianto, 2007).

Pembelajaran berbasis kontekstual akan dapat dilaksanakan secara optimal jika guru dan sekolah memiliki kewenangan sepenuhnya untuk mengatur dirinya sendiri melalui penerapan kebijakan. Kinerja guru akan menjadi acuan keberhasilan siswa dalam mencapai kemampuan yang diinginkan. Oleh karena itu, guru sebagai pihak yang berhadapan langsung dengan siswa harus mempersiapkandiridengansungguh-sungguh. Permasalahannya adalah apakah guruguru sudah benar-benar siap dan mampu mengembangkan serta mengimplementasikan strategi pembelajaran sains yang sesuai dengan kontekstual dan kebutuhan siswa (Mundilarto, 2005).

Berdasarkan pada latar belakang masalah tersebut, maka peneliti melakukan penelitian dengan judul "Pengaruh Model CTL terhadap Hasil Belajar dan Literasi Sains Siswa.

\section{METODE}

\section{Jenis Penelitian}

Jenis penelitian ini adalah eksperimen dapat diartikan sebagai metode penelitian yang digunakan untuk mencari pengaruh perlakuan tertentu terhadap yang lain dalam kondisi yang terkendali (Sugiyono, 2013). Penelitian ini 
adalah quasi experimental (eksperimen semu). Jenis eksperimen ini merupakan pengembangan dari true experimental yang sulit dilaksanakan. Jenis ini mempunyai kelompok kontrol, tetapi tidak dapat berfungsi sepenuhnya untuk mengontrol variabel-variabel luar yang mempengaruhi pelaksanaan eksperimen (Sugiyono, 2014). Dalam penelitian ini, terdapat dua kelas yang masing-masing berfungsi sebagai kelas kontrol dan kelas eksperimen. Kedua kelas tersebut diberikan perlakuan berbeda-beda yakni kelas kontrol diajarkan dengan meodel konvensional sedangkan kelas eksperimen diajarkan dengan menggunakan metode pembelajaran Contekstual Teaching and Learning (CTL).

\section{Variabel Penelitian}

Variabel penelitian adalah suatu atribut atau sifat atau nilai dari seseorang, obyek atau kegiatan yang mempunyai variasi tertentu yang ditetapkan oleh peneliti untuk dipelajari dan kemudian ditarik kesimpulannya dalam penelitian ini menggunakan dua variabel yaitu variabel bebas dan variabel terikat (Sugiyono, 2013).

\section{Variabel Bebas}

Variabel bebas dalam penelitian ini adalah model pembelajaran Contextual Teaching and Learning (CTL) merupakan variabel yang mempengaruhi atau yang menjadi sebab perubahannya atau timbulnya variabel terikat.

\section{Variabel Terikat}

Variabel terikat adalah hasil belajar kognitif dan literasi sains yaitu merupakan variabel yang dipengaruhi atau yang menjadi akibat, karena adanya variabel bebas.

\section{Rancangan Penelitian}

Rancangan penelitian merupakan pedoman yang berisi langkah-langkah yang akan diikuti oleh peneliti untuk melakukan penelitiannya. Rancangan penelitian menggunakan pasca tes dengan cluster sampling (area sampling), teknik sampling daerah digunakan untuk menentukan sampel bila obyek yang akan diteliti atau sumber data sangat luas (Sugiyono, 2013).

\section{Desain Penelitian}

Desain penelitian yang digunakan adalah quasi experimental design dengan jenis "pre-test-post-test non equivalent control group design". Desain inihampir sama dengan pre-test-post-test control group design, hanya pada desain ini kelompok kontrol dan eksperimen tidak dipilih secara acak (Sugiyono, 2013). Pada penelitian melakukan pre-test, untuk mengetahui kemampuan awal siswa sebelum menyampaikan materi dengan mengunakan model pembelajaran CTL. Adapun bagan design pretest-posttest nonequivalent control group design dapat dilihat pada tabel di bawah ini.

Tabel 1. Desain Pre-Test Post-Test Control Group Design

\begin{tabular}{llll}
\hline Kelompok Perlakuan & $\begin{array}{c}\text { Uji Kemampuan } \\
\text { Awal }\end{array}$ & \multicolumn{1}{c}{ Perlakuan } & $\begin{array}{c}\text { Uji Kemampuan } \\
\text { Akhir }\end{array}$ \\
\hline Kelompok & Pre-Test (O1) & Penerapan Model & Post-Test (O2) \\
Eksperimen & & CTL & Post-Test (O4) \\
\hline Kelompok Kontrol & Pre-Test (O3) & $\begin{array}{l}\text { Penerapan Model } \\
\text { Konvensional }\end{array}$ & \\
\hline
\end{tabular}

Sumber: Sugiyono, 2013. 
Berdasarkan Tabel 1 di atas, kelas eksperimen diajarkan melalui model pembelajaran Contekstual Teaching and Learning (CTL). Sedangkan kelas kontrol diajarkan dengan menggunakan model konvensional. sebelum diberi perlakuan kelas kontrol dan kelas eksperimen diuji kemampuan awal yaitu pretes. Setelah kedua kelas diberi perlakuan maka kedua kelas tersebut diberi post-test untuk melihat ada tidaknya pengaruh dari perlakuan yang diberikan.

\section{Populasi dan Sampel}

Populasi adalah wilayah generalisasi yang terdiri atas subyek atau obyek yang mempunyai kualitas dan karakteristik tertentu yang ditetapkan oleh peneliti untuk dipelajari dan kemudian ditarik kesimpulannya. Sedangkan sampel adalah bagian dari jumlah dan karakteristik yang dimiliki oleh populasi tersebut (Sugiyono, 2013).

\section{Populasi}

Populasi dalam penelitian ini adalah seluruh siswa kelas VII SMPN 1 Tanjung tahun pelajaran 2014/2015 yang terdiri dari 6 kelas yaitu kelas VII 1 sampai dengan VII 6, tetapi mengunakan atau mengambil sebagian dari populasi yang ada.

\section{Sampel}

Teknik pengambilan sampel yang digunakan adalah sampling purposive, yaitu teknik pengambilan dengan pertimbangan tertentu. Sehingga sampel dari penelitian ini adalah berdasarkan kelas yang sudah ditetapkan karena populasi yang ada pada kelas VII SMPN 1 Tanjung sangat banyak sehingga menggunakan sampling purposive yaitu penentuan sampel dengan pertimbangan tertentu (Sugiyono, 2014).

\section{Teknik Pengumpulan Data}

Teknik pengumpulan data merupakan langkah yang paling utama dalam penelitian, karena tujuan utama dari penelitian adalah mendapatkan data (Sugiyono, 2013). Dua hal utama yang mempengaruhi kualitas data hasil penelitian yaitu kualitas instrumen penelitian dan kualitas pengumpulan data. Kualitas instrumen penelitian berkenaan dengan validitas dan reliabilitas instrumeninstrumen dan kualitas pengumpulan data berkenaan kecepatan cara yang digunakan untuk mengumpul data. Oleh karena itu, instrumen yang telah teruji validitasnya dan reliabilitasnya, dapat digunakan untuk pengumpulan data.

\section{Instrumen Penelitian}

Instrumen adalah alat yang digunakan untuk mengukur variabel yang diteliti (Sugiyono, 2013). Instrumen penelitian atau alat pengumpul data yang digunakan dalam penelitian ini yaitu berupa tes. Dengan tes diberikan kepada kelas kontrol dan kelas eksperimen untuk mengetahui hasil belajar kognitif dan literasi sains. Instrumen dalam penelitian ini terbagi menjadi dua yaitu instrumen pendukung, instrumenpengukuran dan uji coba instrumen.

Adapun Instrumen yang digunakan dalam penelitian ini adalah sebagai berikut:

1. Instrumen Pendukung

a. Silabus

Silabus merupakan seperangkat rencana dan pengaturan tentang kegiatan pembelajaran, pengelolaan kelas, dan penilaian hasil belajar. Silabus berisikan komponen pokok yang mencakup standar kompetensi, kompetensi dasar, materi pokok/pembelajaran, kegiatan pembelajaran, indikator, penilaian, alokasi waktu, dan sumber/alat/bahan belajar. Silabus merupakan penjabaran standar kompetensi dan kompetensi dasar kedalam materi/pokok 
pembelajaran, dan indikator pencapaian kompetensi untuk penilaian.

b. Rencana Pelaksanaan Pembelajaran (RPP)

Rencana pelaksanaan pembelajaran (RPP) adalah rencana yang menggambarkan prosedur dan pengorganisasian pembelajaran untuk mencapai suatu kompetensi dasar yang ditetapkan dalam standar isi dan dijabarkan dalam silabus. Lingkup rencana pelaksanan pembelajaran (RPP) paling luas mencangkup satu kompetensi dasar yang terdiri dari satu atau beberapa indikator untuk satu kali pertemuan atau lebih. Rencana pelaksanan pembelajaran (RPP) harus disiapkan oleh guru sebelum mengajar. Persiapan disini dapat diartikan persiapan tertulis maupun persiapan mental. Komponen rencana pelaksanan pembelajaran (RPP), yakni identitas mata pelajaran, standar kompetensi, kompetensi dasar, indikator pencapaian kompetensi, tujuan pembelajaran, materi ajar, alokasi waktu, metode pembelajaran dan kegiatan pembelajaran.

c. Lembar Keterlaksanaan RPP

Lembar observasi keterlaksanaan RPP merupakan serangkaian jenis kegiatan yang telah dirancang oleh peneliti yang akan diamati pada saat pembelajaran. Kegiatan yang dimaksud terkait dengan keterlaksanaan RPP dalam proses pembelajaran. Aspek-aspek yang dinilai dalam lembar observasi ini adalah segala kegiatan guru dari awal sampai akhir proses pembelajaran.

2. Instrumen pengukuran

a. Tes hasil belajar

Berupa tes pilihan ganda dengan pilihan sebanyak 20 butir soal, yang digunakan untuk mengukur hasil belajar siswa mengenai materi yang sudah disampaikan. Tes diberikan sebelum dan sesudah dilakukan proses pembelajaran. Tes yang diberikan kepada siswa telah diuji validitas, realibilitas, indeks kesukaran dan daya bedanya (Arikunto, 2011). Tes ini disusun berdasarkan tujuan pembelajaran yang akan dicapai, digunakan untuk mengukur hasil belajar kognitif siswa. Sebelum menyusun tes terlebih dahulu dibuat konsep alat ukur yang disesuaikan dengan tujuan penilaian yang hendak dicapai, selanjutnya indikator ini digunakan sebagai pedoman dalam menyusun item-item tes tertulis. Penyusunan item soal berdasarkan indikator yang telah ditetapkan sebelumnya. Instrumen tes tertulis yang digunakan untuk kelas eksperimen dan kelas kontrol adalah sama, sehingga dapat memberikan data akurat yang dapat mendukung tujuan penelitian.

1) Uji Validitas

Validitas butir soal dimaksudkan untuk mencari soal mana yang dapat mengukur apa yang ingin diukur. Validitas butir soal dicari dengan rumus korelasi product moment (Arikunto, 2011).

2) Uji Reliabilitas.

Uji reliabelitas dimaksudkan untuk mengetahui bahwa soal dapat digunakan berulang. Reliabel soal dicari dengan rumus K-R.20 (Arikunto, 2011).

3) Indeks Kesukaran 
Tabel 2. Klasifikasi Indeks Kesukaran Soal

\begin{tabular}{ccc}
\hline No & Nilai & Kategori \\
\hline 1 & $0,00<\mathrm{P}<0.30$ & Sukar \\
\hline 2 & $0,30 \leq \mathrm{P} \leq 0,70$ & Sedang \\
\hline 3 & $0,70 \leq \mathrm{P} \leq 1,00$ & Mudah \\
\hline
\end{tabular}

Sumber: Arikunto, (2011).

4) Daya Beda

Uji daya beda dimaksudkan untuk mengetahui soal mana yang dapat digunakan untuk membedakan siswa yang pintar dan tidak.

Tabel 3. Klasifikasi Daya Beda

\begin{tabular}{lcc}
\hline No & Nilai & Kategori \\
\hline 1 & $0,00 \leq \mathrm{D} \leq 0,20$ & Jelek \\
\hline 2 & $0,20 \leq \mathrm{D} \leq 0,40$ & Cukup \\
\hline 3 & $0,40 \leq \mathrm{D} \leq 0,70$ & Baik \\
\hline 4 & $0,70 \leq \mathrm{D} \leq 1,00$ & Baik sekali \\
\hline
\end{tabular}

Sumber: Arikunto, (2011).

\section{Teknik Analisa Data}

Analisis data dalam penelitian ini dilakukan dengan teknik statistik deskriptif untuk kemampuan hasil belajar dan literasi sains teknik statistik inferensial yaitu teknik statistik yang digunakan untuk menganalisis data sampel dan hasilnya diberlakukan untuk populasi (Sugiyono, 2013).

1. Uji Homogenitas

Uji homogenitas untuk mengetahui mana yang digunakan, maka harus diketahui apakah kedua data kelompok homogen atau tidak yaitu dengan menggunakan program SPSS 16 for windows.

2. Uji Normalitas

Uji normalitas digunakan untuk mengetahui apakah data post-test terdistribusi normal atau tidak. Uji normalitas dicari dengan menggunakan program SPSS 16 for windows.

3. Uji Hipotesis

Setelah sudah melakukan prasyarat yaitu uji homogen dan uji normalitas maka tes akhirnya diolah dengan menggunakan anova dua jalur dengan bantuan SPSS 16 for windows untuk mengetahui pengaruh model Contextual Teaching and Learning (CTL) terhadap hasil belajar dan literasi sains.

\section{HASILDANPEMBAHASAN}

Deskripsi Data

Penelitian ini telah dilaksanakan dari tanggal 09 maret sampai pada tanggal 04 April 2015, dilakukan sebanyak 4 kali pertemuan yaitu dua kali untuk penyampaian materi, dan 1 kali pretes 1 kali post-tes. Untuk pertemuan pertama dilakukan pada tanggal 09 maret dan untuk post-test dilakukan pada tanggal 04 April. Dalam penelitian ini, data sebelum diberi perlakuan diperoleh dari nilai hasil tes pada materi yang akan di sampaikan yaitu pada materi ekosistem. Sedangkan data kemampuan akhir siswa atau data hasil penelitian diperoleh dari nilai tes setelah perlakuan dan nilai tes pada saat post-test. Data hasil penelitian 
tersebut kemudian dianalisis untuk mendapatkan gambaran tentang pengaruh penerapan model pembelajaran Contextual Teaching and Learning (CTL) terhadap hasil belajar dan literasi sains siswa pada materi ekosistem.

\section{Hasil Uji Coba Instrumen}

Tabel 4. Uji Validitas Soal Pilihan Ganda dan Uraian

\begin{tabular}{lccc}
\hline \multicolumn{1}{c}{ Bentuk Soal } & Jumlah Soal Valid & Jumlah Validitas & Jumlah Tidak Valid \\
\hline Pilihan ganda & 20 & 16 & 4 \\
Uraian & 10 & 7 & 3 \\
\hline
\end{tabular}

Berdasarkan Tabel 4 menunjukkan bahwa, jumlah soal yang valid pada soal pilihan ganda adalah 16 butir soal sedangkan pada soal uraian soal yang valid berjumlah 7 .

Tabel 5. Uji Soal Pilihan Ganda dan Uraian

\begin{tabular}{lcccccc}
\hline \multirow{2}{*}{ Bentuk Soal } & Reliabilitas & \multicolumn{3}{c}{ Tingkat Kesukaran } & \multicolumn{3}{c}{ Daya Beda } \\
\cline { 2 - 7 } & $\begin{array}{c}\text { Nilai } \\
\text { Reliabel }\end{array}$ & Mudah & Sedang & Jelek & Cukup & Baik \\
\hline Pilihan & 0.58 & 0 & 20 & 13 & 4 & 3 \\
Ganda & 1.02 & 0 & 0 & 0 & 0 & 0 \\
Uraian & & & & & & \\
\hline
\end{tabular}

Berdasarkan Tabel 5 pada uji reliabilitas pada soal pilihan ganda dikatakan reliabel karena nilai rhitung > rtabel $(0,58>0,36)$ dan pada soal uraian rhitung > rtabel $(1,02>0,36)$ maka soal tersebut reliabel, sedangkan pada tingkat kesukaran pada bentuk soal pilihan ganda yaitu semua soal dikategorikan sedang dan pada daya beda, kategori jelak berjumlah 13butir soal, cukup, berjumlah 4 butir soal dan kategori baik berjumlah 3 butir soal, dan kriteria keseluruhan dari 20 soaluntuk pilihan ganda adalah soal yang diterima berjumlah 17 butir soal sedang soal yang ditolak berjumlah 3 butir soal.

\section{Hasil Keterlaksanaan RPP}

Tabel 6. Hasil Keterlaksanaa RPP kelas Eksperimen dan Kontrol

\begin{tabular}{lcccc}
\hline \multirow{2}{*}{ Kriteria } & \multicolumn{2}{c}{ Eksperimen } & \multicolumn{2}{c}{ Kontrol } \\
\cline { 2 - 5 } & Pertemuan I & Pertemuan II & Pertemuan I & Pertemuan II \\
\hline $\begin{array}{l}\text { Jumlah aspek yang } \\
\text { diamati }\end{array}$ & 11 & 10 & 10 & 10 \\
\hline Jumlah yang terlaksana & 7 & 8 & 6 & 7 \\
\hline $\begin{array}{l}\text { Jumlah yang tidak } \\
\text { terlaksana }\end{array}$ & 4 & 2 & 4 & 3 \\
\hline Persentase \% & $77 \%$ & $80 \%$ & $60 \%$ & $70 \%$ \\
\hline Kategori & Baik & Sangat Baik & Baik & Baik \\
\hline
\end{tabular}

Berdasarkan hasil observasi keterlaksanaan RPP yang dilakukan oleh observer adalah pada pertemuan pertama untuk kelas eksperimen pada pertemuan pertama dikategorikan baik dilihat pada persentasi yaitu $77 \%$ dan pada pertemuan kedua dikategorikan sangat baik karena presentasinya $80 \%$, dan pada kelas kontrol 
dikategorikan baik dilihat dari persentasinya pada pertemuan pertama $60 \%$ sedang pada pertemuan kedua $70 \%$.

\section{Data Hasil Belajar Kognitif}

Tabel 7. Hasil Belajar Kognitif Kelas Eksperimen dan Kontrol

\begin{tabular}{lcccc}
\hline \multirow{2}{*}{ Parameter } & \multicolumn{2}{c}{ Pre-Test } & \multicolumn{2}{c}{ Post-Test } \\
\cline { 2 - 5 } & Eksperimen & Kontrol & Eksperimen & Kontrol \\
\hline Nilai Tertinggi & 75 & 70 & 95 & 80 \\
\hline Nilai Terendah & 30 & 25 & 50 & 45 \\
\hline Rata-rata & 54.56 & 53.28 & 74.85 & 63.16 \\
\hline
\end{tabular}

Berdasarkan Tabel 7 di atas menunjukkan bahwa, nilai tertinggi pretes pada kelas eksperimen adalah 75 dan pada kelas kontrol 70, dan kelas kontrol nilai terendah pada kelas eksperimen 30 dan kelas kontrol 25, dan pada post-tes nilai tertinggi pada kelas eksperimen 95 sedangkan pada kelas kontrol 80, dan nilai terendah pada kelas eksperimen 50 sedang nilai terendah di kelas kontrol 45, dan rata-rata pretes kelas eksperimen 54,56 sedangkan kelas kontrol 53,28, dan post-tes pada kelas eksperimen 74,85 dan kelas kontrol 63,16. Untuk lebih jelasnya dapat dilihat pada kurva hasil belajar pre-test dan post-test kelas eksperimen dan kelas kontrol di bawah ini.

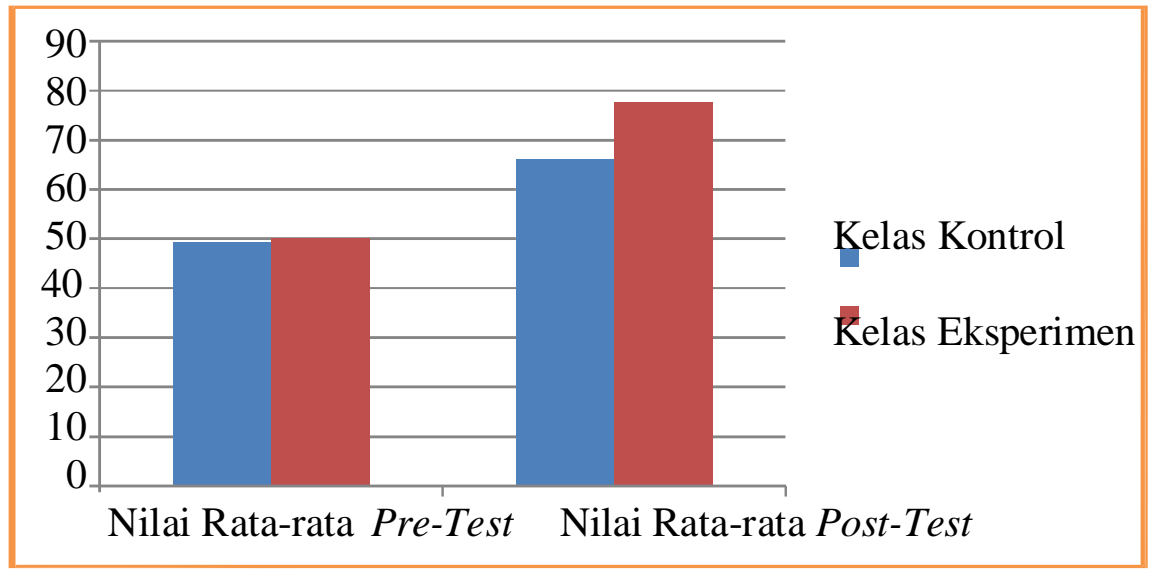

Gambar 1. Kurva Data Hasil Belajar Kognitif

\section{Data Literasi Sains}

\section{Tabel 8. Literasi Sains Siswa Kelas Eksperimen dan Kontrol}

\begin{tabular}{lcccc}
\hline \multirow{2}{*}{ Parameter } & \multicolumn{2}{c}{ Pre-Test } & \multicolumn{2}{c}{ Post-Test } \\
\cline { 2 - 5 } & Eksperimen & Kontrol & Eksperimen & Kontrol \\
\hline Nilai Tertinggi & 65 & 60 & 93 & 80 \\
\hline Nilai Terendah & 40 & 39 & 65 & 55 \\
\hline Rata-rata & 50.26 & 49.41 & 77.74 & 66.17 \\
\hline
\end{tabular}

Berdasarkan Tabel 8 di atas menunjukkan bahwa, nilai tertinggi prêtes pada kelas eksperimen adalah 65 dan pada kelas kontrol 60, dan nilai terendah pada kelas eksperimen 40 dan kelas kontrol 39, dan pada post-tes nilai tertinggi pada kelas eksperimen 93 sedangkan pada kelas kontrol 80, dan nilai terendah pada kelas 
eksperimen 65 sedang nilai terendah di kelas kontrol 55, dan rata-rata pretes kelas eksperimen 50,26 sedangkan kelas kontrol 49,41, dan post-tes kelas eksperimen 77,74 dan kelas kontrol 66,17. Untuk lebih jelasnya dapat dilihat pada kurva literasi sains pre-test dan post-test kelas eksperimen dan kelas kontrol di bawah ini.

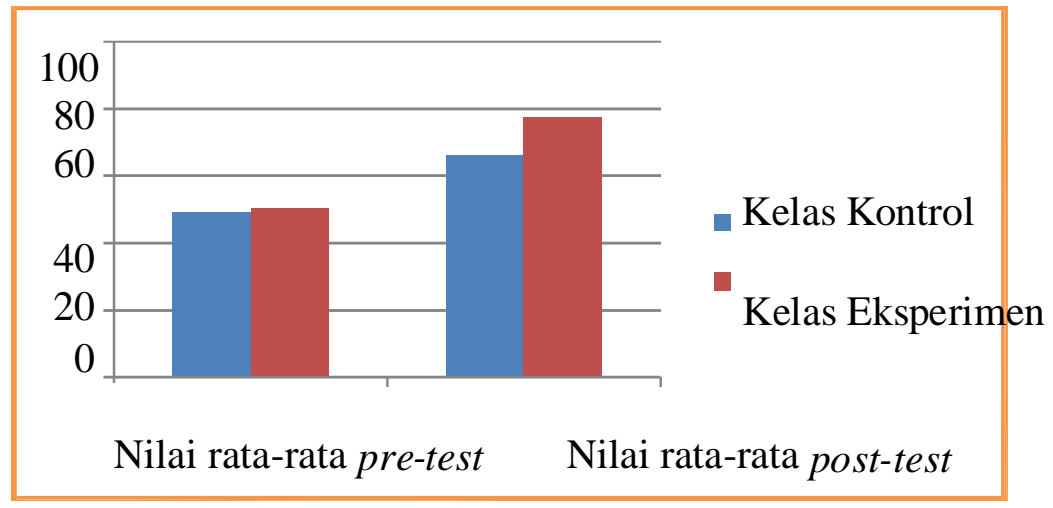

Gambar 2. Kurva Hasil Data Literasi Sains Siswa.

\section{Analisis Data Hasil Belajar Kognitif}

\section{Homogenitas}

Untuk mengetahui apakah data tersebut homogen atau tidak dapat dilihat pada Tabel 9.

Tabel 9. Uji Homogenitas Hasil Belajar Kognitif

\begin{tabular}{lllllll}
\hline Levene Statistic & & df1 & & df2 & & Sig. \\
\hline & .050 & 1 & 64 & .824 \\
\hline
\end{tabular}

Berdasarkan Tabel 9 di atas dapat diketahui bahwa, data hasil belajar siswa yang dilihat dari singnifikan, dimana jumlah signifikan $0.828>0,05$ maka data tersebut homogen.

\section{Uji Normalitas}

Tabel 10. Uji Normalitas Hasil Belajar Kelas Eksperimen dan Kontrol

\begin{tabular}{|c|c|c|c|c|c|c|c|}
\hline & \multirow{3}{*}{$\begin{array}{c}\text { Kelas } \\
\text { Eksperimen } \\
\text { dan Kontrol }\end{array}$} & \multicolumn{3}{|c|}{ Kolmogorov-Smirnova } & \multicolumn{3}{|c|}{ Shapiro-Wilk } \\
\hline & & \multicolumn{6}{|c|}{ Statist } \\
\hline & & Statistic & $\mathrm{df}$ & Sig. & $\mathrm{c}$ & $\mathrm{df}$ & Sig. \\
\hline Kelas & 1 & .171 & 34 & .013 & .944 & 34 & .079 \\
\hline $\begin{array}{l}\text { Eksperimen } \\
\text { dan Kontrol }\end{array}$ & 2 & .159 & 32 & .038 & .936 & 32 & .058 \\
\hline
\end{tabular}

Berdasarkan hasil tabel normalitas diatas bahwa untuk kelas eksperimen signifikan 0,079>0,05 maka data tersebut normal, dan pada kelas kontrol signifikan $0.058>0,05$ maka distribusi normal.

\section{Uji Hipotesis Hasil Belajar Kognitif}

Berdasarkan perhitungan anava dua jalur dengan bantuan SPSS 16.0 bahwa hasil belajar kognitif terdapat perbedaan antara kelas kontrol dan kelas eksperimen dilihat dari jumlah signifikan yaitu $0,000<0,05$ maka Ha diterima yaitu ada pengaruh 
model pembelajaran CTL terhadap hasil belajar kognitif.

Analisis Data Literasi Sains

Uji Homogenitas

Tabel 11. Uji Homogenitas Literasi Sains Kelas Kontrol dan Kelas Eksperimen.

\begin{tabular}{lllllll}
\hline Levene Statistic & & df1 & & df2 & & Sig. \\
& .084 & 1 & 64 & .772 \\
\hline
\end{tabular}

Bardasakan Tabel $11 \mathrm{di}$ atas menunjukkan bahwa, data post-tees literasi sains siswa antara kelas kontrol dan kelas eksperimen dilihat dari signifikanya 0,772> 0,05 maka data tersebut homogen.

\section{Uji Normalitas}

Tabel 12. Uji Normalitas Literasi Sains Siswa Kelas Kontrol dan Kelas Eksperimen.

\begin{tabular}{lccccccc}
\hline & \multirow{2}{*}{$\begin{array}{c}\text { Kelas } \\
\text { Eksperimen } \\
\text { dan Kontrol }\end{array}$} & \multicolumn{3}{c}{ Kolmogorov-Smirnov $^{\mathrm{a}}$} & \multicolumn{4}{c}{ Shapiro-Wilk } \\
\cline { 2 - 8 } & 1 & Statistic & df & Sig. & c & df & Sig. \\
\hline Kelas & 2 & .074 & 34 & .200 & .987 & 34 & .944 \\
\cline { 2 - 8 } $\begin{array}{l}\text { Eksperimen } \\
\text { dan }\end{array}$ & & .138 & 32 & .126 & .967 & 32 & .414 \\
Kontrol & & & & & & & \\
\hline
\end{tabular}

Berdasarkan Tabel 12 di atas, pada Shapiro-Wilk antara kelas kontrol dan kelas eksperimen yang dilihat dari jumlah signifikan $0,944>0,05$ dan pada kelas kontrol signifikan $0,414>0,05$. menujukan bahwa data tersebut normal.

\section{Uji Hipotesis}

Berdasarkan hasil perhitungan SPSS 16 anava dua jalur dilihat dari signifikanya antara kelas kontrol dan kelas eksperimen, dilihat dari jumlah signifikanya yaitu $0,000<0,05$ maka Ha diterima ada pengaruh model pembelajar CTL terhadap literasi sains siswa.

\section{Pembahasan}

\section{Hasil Uji Coba Instrumen}

Uji coba istrumen dilakukan untuk mengetahui instrument tersebut dapat digunaka, untuk mengupulkan data atau tidak yaitu dengan acara validitas, reabilitas, tingkat kesukaran, dan daya beda. yang dilakukan pada siswa kelas VIII SMPN 1 Tajung, dari beberapa pengujian soal yang dapat diteriama atau yang dapat digunakan adalah 17 butir soal butir soal. Sedangkan pada soal uraian hanya menghitung validitas dan reabilitas denagan jumlah soal sebanyak 10 butir soal.

\section{Hasil Keterlaksanaan RPP}

Rencana pelaksanaan pembelajaran merupakan salah satu perangkat pembelajaran yang harus dipersiapkan guru sebelum proses pembelajaran berlangsung di dalam kelas. RPP harus disusun oleh guru sebagai gambaran kegiatan guru selama proses pembelajaran di dalam kelas. Berdasarkan Tabel 4.4, data hasil observasi keterlaksanaan pembelajaran memiliki kategori baik, dan sangat baik hal ini disebabkan oleh matangnya persiapan yang dilakukan guru sebelum mulai pembelajaran, tersedianya sumber belajar (buku, LKS), alat bahan dan 
lingkungan belajar (kelas, lingkungan sekitar) yang mendukung proses belajar siswa. Pertemuan pertama pada kelas eksperimen dilihat dari rata-rata keterlaksanaan $77 \%$, dikategorikan baik karena waktu yang dibutuhkan untuk pembelajaran tidak cukup, dan di kelas kontrol $60 \%$ kategori baik karena waktu untuk pembelajaran tidak cukup. Sedang pada pertemuan kedua pada kelas eksperimen keterlaksanaan pembelajaran $80 \%$, sedangkan pada kelas kontrol $70 \%$ karena materinya untuk pertemuan kedua waktunya sangat cukup sehingga perencanaan pembelajaran tercapai.

\section{Data Hasil Belajar Kognitif}

Data hasil belajar yang dilihat dari nilai pretes dan post-tes antara kelas kontrol dan kelas eksperimen, nilai tertinggi pretes pada kelas eksperimen adalah 75 sedangkan pada kelas kontrol nilai yang tertinggi adalah 70 sedangkan nilai terendah pada kelas eksperimen adalah 30 dan pada kelas kontrol 25. Pada kelas eksperimen nilai tertinggi adalah 95 sedangkan pada kelas kontrol nilai tertinggi adalah 80, dan nilai terendah pada kelas eksperimen adalah 50 dan pada kontrol 45, berdasrkan rata-rata hasil yang diperoleh dari dua kelompok kelas tersebut maka kelompok kelas yang mendapat nilai rata-rata paling tinggi dijadikan kelas eksperimen sedangkan kelas yang memperoleh nilai rata-ratanya rendah dijadikan kelas kontrol atau kelas pembanding.

\section{Data Literasi Sains}

Berdasarkan hasil data pretes dan post-tes literasi sains antara siswa kelas eksperimen dan kelas kontrol, bahwa nilai tertinggi pretes pada kelas eksperimen adalah 65 dan pada kelas kontrol nilai tertingginya adalah 60, sedangkan nilai terendah pada kelas eksperimen adalah 40 dan pada kelas kontrol adalah 39. Dan pada post-tes nilai tertinggi pada kelas eksperimen 93 dan kelas kontrol 80, sedangkan nilai terendahnya pada kelas eksperimen adalah 65dan kelas kontrol 55. Berdasrkan rata-rata hasil yang diperoleh dari dua kelompok kelas tersebut maka kelompok kelas yang mendapat nilai rata-rata paling tinggi dijadikan kelas eksperimen sedangkan kelas yang memperoleh nilai rata-ratanya rendah dijadikan kelas kontrol atau kelas pembanding.

\section{Data Hasil Belajar Kognitif}

Berdasarkan hasil pengelolahan dan analisis data secara statistik anava dua jalur dengan mengunakan bantuan SPSS 16.0 dan hipotesis yang peneliti ajukan di lapangan bahwa dengan mengunakan model pembelajaran CTL berpengaruh terhadap hasil belajar kognitif siswa, hal ini sejalan dengan penelitian Yaum (2013), dengan judul "Pengaruh Pembelajaran Komperatif Two Stay Two Stray dengan pendekatan Contextual Teaching and Learning (CTL) terhadap Motivasi dan Hasil Belajar Biologi Siswa Kelas X SMA Negeri Negara" bahwa adanya perbedaan yang signifikan antara siswa yang diajarkan dengan pembelajaran Two Stay Two Stray dengan pendekatan Contextual Teaching and Learning (CTL) dan siswa yang diajarkan dengan pembelajaran konvensional.

Ha 1 ini terbukti bahwa dengan meggunaka $n$ model CTL d ap at memb antu siswa untuk melatih mengembangkan pemikiran dengan cara bekerja sendiri, menemukan pengetahuan baru, karena pembelajaran CTL membantu siswa $u$ ntuk mengkaitkan antara ilmu yang didapatkan dengan kehidupan sehari-hari. Sehingga siswa lebih aktif dan bisa berinteraksi dengan lingkangan sekitar dan dapat menciptakan ke lompok belajar (Trianto, 2007). Model CTL merupakan suatu proses pendidikan yang holistik dan bertujuan motivasi siswa. 
Pembelajaran ini digunakan untuk memahami makna materi pelajaran yang dipelajari siswa dengan mengkaitkan materi tersebut dalam konteks kehidupan mereka sehari-hari konteks pribadi, sosial, dan kultur, sehingga siswa memiliki pengetahuan yang fleksibel dapat diterapkan dari satu permasalahan lainnya dan juga membantu guru mengkaitkan antara materi yang diajarkan dengan situasi dunia nyata, model ini mendorong pelajaran membuat hubungan antara materi yang dipelajari dengan penerapan dalam kehidupan mereka sebagai angota keluarga dan masyarakat (Aqib, 2013). Sehingga dapat menarik kesimpulan atau hipotesis yang muncul berdasarkan perhitunga anava dua jalur dengan bantuan SPSS versi16 dilihat dari signifikannya yaitu $0,000<0,05$ terbukti bahwa model pembelajaran CTL berpengaruh hasil belajar kognitif siswa.

\section{Data Literasi Sains}

Literasi sains memiliki tiga indikator yairu konten, konteks dan proses, untuk memperoleh kempuan literasi sains siswa yang dengan cara mengerjakan soal uraian untuk mengetahui konten dan konteks sains sedangkan untuk mengetahui proses sains dapat diperoleh dari LKS. Penelitian ini sejalan dengan penelitian Sukerthi (2013), yang berjudul "Pengaruh Model Pembelajaran Tandur dalam Pembelajaran Geografi terhadap Literasi Sains dan Prestasi Belajar Siswa Kelas XI IPS SMAN 2 Amlapura" menyatakan bahwa terdapat perbedaan kemampuan literasi sains dan prestasi belajar antara siswa yang mengikuti model pembelajaran tandur dengan siswa yang mengikuti model pembelajaran konvensional.

Pembelajaran Contextual Teaching and Learning (CTL) adalah konsep belajar di mana guru menghadirkan dunia nyata ke dalam kelas dan mendorong siswa membuat hubungan antara pengetahuan yang dimilikinyadengan penerapannya dalam kehidupan merekasehari-hari, sementarasiswa memperoleh pengetahuan dan keterampilan dari konteksyang terbatas sedikit demi sedikit, dan dari proses mengkonstruksi sendiri, sebagai bekal untuk memecahkan masalah dalam kehidupannya sebagai anggota masyarakat (Nurhadi, 2003 dalam Trianto, 2007). Pendekatan Contextual

Teaching and Learning (CTL) merupakan konsep belajar yang membantu guru mengaitkan antara materi yang diajarkan dengan situasi dunia nyata siswa, dan mendorong siswa membuat hubungan antara pengetahuan yang dimilikinya dengan penerapannya dalam kehidupan mereka sebagai anggota keluarga dan masyarakat (Trianto, 2007).

Berdasrkan hasil analisis data sebelum melakukan uji hipotesis terlebih dahulu melakukan uji prasyarat yaitu uji homogen dan uji normalitas, maka analisis data menggunakan anova dua jalur dengan bantuan SPSS versi16 atau multivariet dengan signifikan $0,000<0,05$, dapat disimpulkan ada pengaruh model pembelajaran CTL terhadap hasil belajar kognitif.

\section{KESIMPULAN DAN SARAN Kesimpulan}

Berdasarkan hasil dan pembahasan di atas, dapat diambil kesimpulan bahwa : 1) ada pengaruh model pembelajaran Contextual Teaching and Learning (CTL) terhadap hasil belajar kognitif $(\mathrm{p}(0,000)<\alpha(0,05))$; dan 2$)$ ada pengaruh model pembelajaran Contextual Teaching and Learning (CTL) terhadap literasi sains .(p $(0,000)<\alpha(0,05))$.

\section{Saran}

Sebagai tindak lanjut dari hasil penelitian ini, maka dapat dikemukakan beberapa 
saran sebagai berikut:

1. Diharapkan kepada guru mata pelajaran IPA untuk mengukur literasi sains siswa dalam setiap materi yangmelaksanakan kegiatan praktikum pada materi apa saja agar siswa terbiasa dengan bahasa latin yang berada pada mata pelajaran IPA terutama pada materi biologi seperti ekosistem dan meraka biasa mengkaitkan antara materi yang mereka pelajari dengan kehidupan mereka sehari-hari.

2. Pada proses pembelajaran sebaiknyaperan gurudikurangi agar tidak mendominasi kelas dan memberikan kesempatan kepada siswa untuk terlibat langsung dalam pembelajaran, sehingga siswa secara aktif melibatkan diri dalam proses menemukan konsep materi itu sendiri.

3. Bagi peneliti selanjutnya, diharapkan untuk mencoba menerapkan model pembelajaran Contextual Teaching and Learning pada materi IPA khususnya pada materi biologi lainnya.

\section{DAFTAR RUJUKAN}

Amri, S. (2010). Proses Pembelajaran Kreatif dan Inovatif dalam kelas. Jakarta: PT. Prestasi Pustakaraya.

Aqib, Z. (2013). Model-model Media dan Strategi Pembelajaran Kontekstual Inovatif. Bandung: Yrama Widya.

Arikunto, S. 2011. Prosedur Penelitian Satuan Pendekatan Praktik. Jakarta: Rineka Cipta.

Bahtiar, Prayogi, S. 2012. Evaluasi Pembelajaran Sains. Mataram: CV. Dimensi Raya.

Hendriani, Y. 2013. Pengaruh Pembelajaran IPA Terpadu terhadap Pengembangan Literasi Sains Siswa SMPN 3 Cimahi dan SMPN 1 Lembang. Pusat Pemberdayaan Pendidik Dan Tenaga Kependidikan Ilmu Pengetahuan Alam Bandung.

Misrun. 2013. Pengaruh Model Contextual Teaching and Learning (CTL) terhadap pemahaman Konsep dan Kemampuan Pemecahan Masalah dalam Pembelajaran IPA-Fisika di MTs Negeri Negara.

Mundilarto. 2005. Pendekatan Kontekstual Dalam Pembelajaran Sains. Yogyakarta: Mlati Sleman.

Purwanto. 2013. Evaluasi Hasil Belajar. Yogyakarta: Pustaka Belajar.

Setiatava, R.P. 2013. Desain Belajar Mengajar Kreatif Berbsis sains.Jogjakarta: Diva press.

Slameto. 2010. Belajar dan Faktor-Faktor yang Mempengaruhinya. Jakarta: Rineka Cipta.

Sugiyono. 2011. Metode Penelitian Kuantitatif, Kualitatif, dan R\&D. Bandung: Alfabet CV. . 2013. Metode Penelitian Pendidikan Pendekatan kuantitatif, kualitati, dan $R \& D$. Bandung Alfabet CV: Bandung. . 2014. Statistik Untuk Penelitian. Bandung: Alfabet CV.

Sukerthi, M.D, dkk. 2013. Pengaruh Model Pembelajaran Tandur dalam Pembelajran Geografi terhadap Literasi sain dan Prestasi Belajar Siswa Kelas XI IPS SMA Negeri 2 Amlapura. Universitas Pendidikan Ganesha.

Suparno, P. 2013. Metodelogi Pembelajaran Fisika Konstruktifistik dan menyenangkan. Yogyakarta : Universitas Senata Dharma. 
Suprijono. 2011. Comperatif Learning Teori dan Aplikasi Paikem. Yogyakarta: Pustaka Belajar.

Trianto. 2007. Model-Model Pembelajaran Inovatif berorientasi Konstruktiifistik. Jakarta: Prestasi Pustaka.

Yaum, K. (2013). Pengaruh Model Pembelajara Koomperatif Two Stay Two Stray dengan Pendekatan Contextual Teaching and Learning Terhadap Motivasi dan Hasil Belajar Biologi Siswa Kelas X SMA Negeri 1 Tumpang. Universitas Negeri Malang. 